\title{
ХАРАКТЕРИСТИКА ХВОРИХ ІЗ НАСЛІДКАМИ ЧЕРЕПНО-МОЗКОВОЇ ТРАВМИ ЗА ПРОВІДНИМ НЕВРОЛОГІЧНИМ ПОСТТРАВМАТИЧНИМ СИНДРОМОМ
}

\section{@3. В. Салій, С. І. Шкробот, М. І. Салій}

Тернопільський національний медичний університет імені І. Я. Горбачевського МОЗ України

РЕЗЮмЕ. Клінічно наслідки ЧМТ складаються із спектра соматичних, неврологічних і психіатричних симптомів. Завдання клініциста полягає в розумінні причин виникнення окремих симптомів, їх взаємодії.

Мета - оцінити поширеність та динаміку основних клінічних синдромів у хворих із наслідками ЧМТ залежно від тяжкості та катамнезу травми.

Матеріал і методи. Проведено оцінку клінічної картини у 367 хворих з наслідками ЧМТ, середній вік $(42,72 \pm 0,51)$ років (легкої ЧМТ - у 99, середньої тяжкості - у 118 та тяжкої ЧМТ - у 150 пацієнтів). За катамнезом травми пацієнти були поділені на чотири групи: до 1 року, 1-5 років, 6-10 років та більше 10 років. Провідні клінічні синдроми виділяли за класифікацією наслідків ЧМТ (Ліхтерман Л. Б.).

Результати. Ізольовані клінічні синдроми діагностували у 54,5 \% хворих з лЧМТ, у 37,3 \% - з СТЧМТ та у 20,6 \% пацієнтів з ТЧМТ.

Висновки. У віддаленому періоді ЧМТ домінували синдром психічної дисфункції та церебрально-вогнищевий. 3 подовженням катамнезу ЧМТ зростав відсоток пацієнтів, у яких у клінічній картині поєднувалося декілька синдромів: ЛЧМТ - від 18,2 \% (при катамнезі до 1 року) до 75 \% (при катамнезі більше 10 років), СТЧМТ - від 57,1 \% (до 1 року) до 69,2 \% (більше 10 років), ТЧМТ - від 71,0 \% (до 1 року) до 86,5 \% (більше 10 років).

ключовІ СловА: черепно-мозкова травма; катамнез травми; клінічні синдроми; шкала NOS-TBI.

Вступ. На відміну від гострої черепно-мозкової травми (ЧМТ), епідеміологія ії наслідків повномасштабно досліджена в силу цілої низки факторів. У 50-80 \% випадків після ЧМТ формується симптомокомплекс, схильний до періодів декомпенсації та прогресування, спричиняючи як тимчасову, так і стійку втрату працездатності. Тільки в США кількість пацієнтів, які отримали інвалідність унаслідок ЧМТ, сягнула 3 млн осіб, і, згідно 3 даними літератури, має тенденцію до зростання [1]. Проте, незважаючи на масштабність проблеми, дискусійними залишаються багато аспектів, як от визначення самого поняття "наслідки ЧМТ», систематизації та єдиної класифікації, ролі первинних та вторинних патогенетичних механізмів у розвитку клінічної картини.

Згідно з визначенням Ліхтермана Л. Б. і співавт. [2], наслідки ЧМТ - це еволюційно обумовлений та генетично закріплений комплекс дистрофічних, дегенеративних, автоімунних, резорбтивних, репаративних та інших процесів, що розвиваються у відповідь на пошкодження головного мозку та його покривів. Клінічно наслідки ЧМТ складаються із спектра соматичних, неврологічних і психіатричних симптомів. Завдання клініциста полягає в розумінні причин виникнення окремих симптомів, їх взаємодії. Лише комплексна оцінка і міждисциплінарний підхід дадуть можливість проводити диференційну діагностику, необхідну для розробки плану реабілітації, який максимізує відновлення [3].

Мета - оцінити поширеність та динаміку основних клінічних синдромів у хворих із наслід- ками ЧМТ залежно від тяжкості та катамнезу травми.

Матеріал і методи дослідження. Проведено оцінку клінічної картини у 367 хворих із наслідками ЧМТ, середній вік - $(42,72 \pm 0,51)$ років, чоловіків було 313 (85,29 \%). 99 пацієнтів перенесли легку ЧМТ (ЛЧМТ) (середній вік $(43,50 \pm 0,95)$ років, катамнез травми $(6,82 \pm 0,69)$ років); 118 - середньої тяжкості ЧМТ (СТЧМТ) - $(44,06 \pm 0,86)$ років, катамнез травми $(9,89 \pm 1,10)$ років та 150 хворих тяжку ЧМТ (ТЧМТ) (середній вік - $(42,39 \pm 1,10)$ років, катамнез - $(8,90 \pm 0,68)$ років). За катамнезом ЧМТ пацієнтів поділили на чотири групи: до 1 року, 1-5 років, 6-10 років та більше 10 років. Згідно з класифікацією наслідків ЧМТ [2] виділяють шість провідних клінічних синдромів.

Статистична обробка результатів проведена за допомогою програмного пакета Statsoft Statistica 6.1.

Результати й обговорення. Клінічна характеристика віддаленого періоду ЧМТ базувалася на аналізі суб'єктивних даних, клініко-неврологічному обстеженні з виділенням провідних клінічних синдромів, об'єктивізації неврологічного статусу з використанням шкали NOS-TBI, дослідженні когнітивної сфери та рівня тривожності й депресії.

У віддаленому періоді лчМТ діагностовано такі синдроми: цефалгічний (92,9 \%), емоційнолабільний астенічний $(45,4 \%)$, вестибулярний (34,3\%), рефлекторної пірамідної недостатності (25,3 \%), екстрапірамідної недостатності (16,2 \%), лікворно-гіпертензійний (13,1\%), епілептичний $(11,1 \%)$. Аналізуючи поширеність цих синдромів 
Огляди літератури, оригінальні дослідження, погляд на проблему, випадок з практики, короткі повідомлення

у групах із різним катамнезом встановили таке: при сталій частоті цефалгічного, вестибуло-атактичного, астенічного та пірамідного синдромів із подовженням посттравматичного періоду зростала частка хворих із екстрапірамідними (від 4,0\% (при катамнезі 1-5 років) до 31,2 \% (при катамнезі більше 10 років)) та когнітивними розладами (від 16 \% до 25 \% відповідно), а також із порушенням слуху.

У віддаленому періоді СТЧМТ клінічна картина доповнювалася синдромами когнітивного зниження (28,8 \%) та бульбарним (8,5 \%), руховими розладами у вигляді парезу (16,1 \%). Частіше діагностували пароксизмальні стани: судоми (20,3%), лікворно-гіпертензійні (16,9\%), церебрально-судинні (3,4 \%) й вегетативні (2,5\%) кризи. Аналіз клінічних синдромів через призму катамнезу засвідчив, що прояви бульбарного синдрому, окорухові та афатичні розлади діагностували лише при катамнезі ЧМТ до 5 років, астено-депресивний синдром - при катамнезі травми більше 5 років. Найбільша частка пацієнтів із епілептичним синдромом була у групах із тривалістю посттравматичного періоду 1-5 років та більше 10 років. Подовження періоду після чМТ супроводжувалося зростанням частки екстрапірамідних (від 7,5 \% до 15,4 \% (більше 10 років)) та когнітивних (від 3,6 \% (1-5 років) до 50 \% (більше 10 років)) розладів.

У групах із різним катамнезом ТЧМТ відносно стабільним залишався відсоток хворих з цефалгічним, афатичним та екстрапірамідним синдромами (9,7 \% - до 1 року, 13,2 \% - більше 10 років) при достовірному ( $<<0,05)$ зростанні частки пацієнтів з когнітивним зниженням (25,8 \% - до 1 року, 43,2 \% - більше 10 років), судомами (9,7 \% - до 1 року, 42,1 \% - понад 10 років), лікворно-гіпертензійними кризами (3,2 \% - до 1 року, 13,2 \% понад 10 років) та вестибуло-атактичним синдромом (6,4 \% - до 1 року, 28,9 \% - понад 10 років).

У загальній вибірці неврологічний дефіцит за NOS-TBI було оцінено як легкий - $(3,16 \pm 0,12)$ бала. Незалежно від тяжкості перенесеної ЧМТ, у віддаленому періоді діагностували легкий неврологічний дефіцит: ЛЧМТ - $(2,19 \pm 0,17)$ бала, СТЧМТ $(2,67 \pm 0,18)$ бала, ТЧМТ - $(4,16 \pm 0,20)$ бала. Встановлено достовірну кореляцію тяжкості перенесеної травми з результатом NOS-TBI $(r=0,35 ; p=0,001)$. У віддаленому періоді ТЧМТ неврологічний дефіцит був обумовлений, в основному, наявністю рухових (парез) та мовних (афазія, дизартрія) розладів. Частка пацієнтів із нулем балів за NOS-TBI $19,2 \%$ (ЛЧМТ) та 11,0 \% (СТЧМТ) р<0,05.

Виявлено достовірні відмінності значень NOS-TBI у групах, поділених за критерієм катамнезу ЧМТ. У віддаленому періоді ЛЧМТ достовірно вищі $(p<0,05)$ значення шкали мали пацієнти з ка- тамнезом у 1-5 років та більше 10 років, у віддаленому періоді СТЧМТ - з катамнезом травми у 6-10 років. Водночас між групами з різною тривалістю віддаленого періоду ТЧМТ таких відмінностей не зафіксовано. 3 подовженням катамнезу лЧМТ на тлі зменшення частки пацієнтів із руховими та сенсорними розладами зростав відсоток пацієнтів зі зниженням слуху та атаксією ходи. Динаміка кількості хворих, у яких неврологічний дефіцит становив нуль балів, була такою: 38,5 \% хворих (катамнез до 1 року), 12,0 \% (1-5 років), 12,5 \% (6-10 років) та 9,4 \% (більше 10 років). Незалежно від катамнезу СТЧМТ реєстрували схожі тенденції у поширеності провідних клінічних симптомів. Частка хворих із нулем балів (за шкалою NOS-TBI) була сталою (р>0,05): 14,3 \% (до 1 року) та 11,5 \% (більше 10 років).

Клініка віддаленого періоду ТЧМТ мала такі особливості: найбільша частка хворих з афазією та парезом кінцівок була при катамнезі до 1 року, поширеність розладів чутливості зменшувалася при подовженні катамнезу, а відсоток хворих із атаксією в кінцівках зменшився при стабільному відсоткові хворих з атаксією ходи. Динаміка кореляцій катамнезу лчМТ й СТЧМТ із неврологічним дефіцитом дозволила припустити, що в перші 5 років після травми ще тривають процеси репаративного характеру.

3 метою дослідження можливих клінікоструктурних співвідношень хворих з наслідками СТЧМТ та ТЧМТ поділили на чотири групи: перша $(n=56)$ - без змін на МСКТ головного мозку, друга (n=133) - з ознаками лише атрофічного процесу головного мозку, третя - з одиничною кістою ( $n=62$ ) та четверта ( $n=59)$ - $з$ наявністю двох і більше кіст головного мозку. Достовірних відмінностей результатів шкали NOS-TBI у вказаних групах встановлено не було: за відсутності змін на МСКТ головного мозку - $(2,04 \pm 0,30)$ бала, за наявності

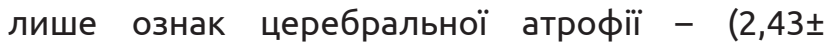
0,34) бала, однієї посттравматичної кісти головного мозку - $(2,95 \pm 0,31)$ бала, двох і більше кіст $(3,05 \pm 0,48$ бала) p>0,05. Аналізуючи окремі рубрики шкали ми встановили, що за наявності посттравматичних лікворних кіст діагностували парези кінцівок (одиничні та множинні кісти), афазії та дизартрію (множинні кісти), більшою була частка пацієнтів із атаксією в кінцівках (множинні кісти); дифузний атрофічний процес частіше $(p<0,05)$ поєднувався з порушенням слуху та атаксією ходи. Група без змін на МСКТ головного мозку утримувала лідерство за зниженням слуху, поширеністю атактичних розладів та розладів чутливості.

Наступним кроком була оцінка клінічної картини віддаленого періоду ЧМТ, базуючись на класифікації Ліхтермана Л. Б. (2004). Клінічна карти- 
Огляди літератури, оригінальні дослідження, погляд на проблему, випадок з практики, короткі повідомлення на віддаленого періоду лчМТ була представлена моносиндромально у 54,5 \% хворих, віддаленого періоду СТЧМТ - у 37,3 \%,віддаленого періоду ТЧМТ - 20,6 \%, у решти пацієнтів - комбінацією двох і більше синдромів.

При ЛЧМТ прояви психічної дисфункції частіше поєднувалися з церебрально-вогнищевим, вестибулярної дисфункції та лікворно-динамічним синдромами. У віддаленому періоді СТЧМТ співвідношення було схожим, проте ізольовано синдром психічної дисфункції траплявся втричі рідше. У групі з наслідками ТЧМТ найпоширенішим було поєднання церебрально-вогнищевого та синдрому психічної дисфункції (28,7 \%), частота решти комбінацій була на порядок меншою. 3 подовженням катамнезу зростав відсоток пацієнтів, у яких в клінічній картині поєднувалося декілька синдромів: ЛЧМТ - від 18,2 \% (при катамнезі до 1 року) до 75 \% (при катамнезі більше 10 років),

СТЧМТ - від 57,1 \% (в групі до 1 року) до $69,2 \%$ (більше 10 років), ТЧМТ - від 71,0 \% (до 1 року) до $86,5 \%$ (більше 10 років).

Висновки. 1. Клініка наслідків черепно-мозкової травми була представлена одним синдромом у 54,5 \% хворих з ЛЧМТ, у $37,3 \%$ - з СТЧМТ та у 20,6 \% пацієнтів з ТЧМТ. Незалежно від тяжкості чМТ найчастіше діагностували синдром психічної дисфункції та церебрально-вогнищевий.

2. 3 подовженням катамнезу ЧМТ зростав відсоток пацієнтів, у яких в клінічній картині поєднувалося декілька синдромів: ЛЧМТ - від 18,2 \% (при катамнезі до 1 року) до 75 \% (при катамнезі більше 10 років), СТЧМТ - від 57,1 \% (до 1 року) до 69,2 \% (більше 10 років), ТЧМТ - від 71 \%, (до 1 року) до $86,5 \%$ (більше 10 років).

Перспективи подальших досліджень. Встановлення можливого взаємозв'язку між морфологічними та клінічними наслідками ЧМТ.

\section{ЛITEPATУPA}

1. Roozenbeek B. Changing patterns in the epidemiology of traumatic brain injury/B. Roozenbeek, A. I. R. Maas, D. K. Menon // Nat. Rev. Neurol. - 2013. - Vol. 9 (4). P. 231-236.

2. Лихтерман Л. Б. Периодизация течения ЧМТ.

Нейротравматология : справочник / Л. Б. Лихтерман. М. : Вазар-Ферро, 1994. - 415 с.

3. Riggio S. Traumatic brain injury and its neurobehavioral sequelae / S. Riggio // Neurol. Clin. - 2011. Vol. 29 (1). - P. 35-47.

\section{REFERENCES}

1. Roozenbeek, B., Maas, A.I., \& Menon, D.K. (2013). Changing patterns in the epidemiology of traumatic brain injury. Nat. Rev. Neurol., 9 (4), 231-236.

2. Likhterman, L.B. (1994). Periodizatsiya techeniya CHMT. Neyrotravmatologiya: Spravochnik [Periodization

of the TBI flow. Neurotraumatology: handbook]. Moscow: Vazar-Ferro [in Russian].

3. Riggio, S. (2011). Traumatic brain injury and its neurobehavioral sequelae. Neurol. Clin., 29 (1), 35-47.

\section{ХАРАКТЕРИСТИКА БОЛЬНЫХ С ПОСЛЕДСТВИЯМИ ЧЕРЕПНО-МОЗГОВОЙ ТРАВМЫ ПО ВЕДУЩЕМУ НЕВРОЛОГИЧЕСКОМУ ПОСТТРАВМАТИЧЕСКОМУ СИНДРОМУ}

Тернопольский национальный медицинский университет имени И. Я. Горбачевского МОз Украины

РЕЗЮМЕ. Клинически последствия ЧМТ состоят из спектра соматических, неврологических и психиатрических симптомов. Задача клинициста заключается в понимании причин возникновения отдельных симптомов, их взаимодействия.

Цель - оценить распространенность и динамику основных клинических синдромов у больных с последствиями ЧМТ в зависимости от тяжести и катамнеза травмы.

Материал и методы. Проведена оценка клинической картины у 367 больных с последствиями ЧМТ, средний возраст - $(42,72 \pm 0,51)$ лет (легкой ЧМТ - у 99, средней тяжести - у 118 и тяжелой ЧМТ - у 150 пациентов). Согласно катамнезу травмы пациенты были поделены на четыре группы: до 1 года, 1-5 лет, 6-10 лет и более 10 лет. Характеристика ведущих клинических синдромов проведена согласно классификации последствий чМТ (Лихтерман Л. Б.).

Результаты. Изолированные клинические синдромы диагностировали у 54,5 \% больных с лЧМТ, у 37,3 \% со СТЧМТ и у $20,6 \%$ пациентов с ТЧМТ. 
Огляди літератури, оригінальні дослідження, погляд на проблему, випадок з практики, короткі повідомлення

Выводы. В отдаленном периоде чМТ доминировали синдром психической дисфункции и церебрально-очаговый. С удлинением катамнеза ЧМТ увеличился процент пациентов, у которых в клинической картине сочеталось несколько синдромов: ЛЧМТ - от 18,2 \% (при катамнезе до 1 года) до 75 \% (при катамнезе более 10 лет), СТЧМТ - от 57,1% (до 1 года) до 69,2 \% (более 10 лет), ТЧМТ - от 71 \% (до 1 года) до 86,5 \% (более 10 лет).

КЛЮчЕВЫЕ СЛОВА: черепно-мозговая травма; катамнез травмы; клинические синдромы; шкала NOS-TBI.

\section{CHARACTERISTICS OF PATIENTS WITH CONSEQUENCES OF CRANIAL INJURY ON CONDUCTIVE NEUROLOGICAL POSTTRAUMATIC SYNDROME}

\section{@Z. V. Salii, S. I. Shkrobot, M. I. Salii}

\section{Horbachevsky Ternopil National Medical University}

SUMMARY. Clinically, the consequences of TBI consist of a range of somatic, neurological and psychiatric symptoms. The task of the clinician is to understand the causes of individual symptoms, their interaction.

The aim - was to evaluate the prevalence and dynamics of the main clinical syndromes in patients with the consequences of TBI depending on the severity and catamnesisof the injury.

Material and Methods. The clinical picture was assessed in 367 patients with the consequences of TBI, the mean age - (42.72 \pm 0.51$)$ years (mild trauma - in 99, moderate - in 118 and severe trauma - in 150 patients). According to the catamnesis of the injury, patients were divided into four groups: up to 1 year, 1-5 years, 6-10 years and more than 10 years. Characterization of the leading clinical syndromes was carried out according to the Lichterman's classification of the consequences of TBI.

Results. Isolated clinical syndromes were diagnosed in $54.5 \%$ of patients with mild TBI, in $37.3 \%$ - with moderate severity and in $20.6 \%$ of patients with severe TBI.

Conclusions. Mental dysfunction and cerebral focal syndrome was dominated in the remote period of TBI. With the prolongation of the catamnesis of TBI, the percentage of patients with a combination of several syndromes in the clinical picture increased: mild TBI - from $18.2 \%$ (with catamnesis up to 1 year) to $75 \%$ (with catamnesis of more than 10 years), moderate severity TBI - from $57.1 \%$ (up to 1 year) to 69.2\% (more than 10 years), severe TBI - from $71 \%$ (up to 1 year) to $86.5 \%$ (more than 10 years).

KEY WORDS: traumatic brain injury; catamnesis of trauma; clinical syndromes; NOS-TBI scale.

Отримано 22.03.2021 